\title{
A simple storage based floodplain inundation modelling approach in AWRA-R for estimating floodplain fluxes
}

\author{
Dushmanta Dutta, Julien Lerat, Justin Hughes, Shaun Kim, Jai Vaze \\ CSIRO Land and Water, Canberra, ACT, Australia \\ Email: dushmanta.dutta@csiro.au
}

\begin{abstract}
Floodplains are a critical part of the natural environment and they play important ecological and hydrological roles in river basins. For example, the Murray-Darling Basin (MDB) in Australia has over 30,000 floodplains and wetlands, which provide a range of ecological benefits.

The Australian Water Resources Assessment (AWRA), built as part of the Water Information Research and Development Alliance (WIRADA) between CSIRO and the Bureau of Meteorology (BoM), is designed to support BoM in the production of the National Water Accounts and AWRA reports, which provides an overview of water fluxes and storages at the national scale. AWRA-R, one of the three components of the AWRA system, focuses on river systems including fluxes and storages in floodplains. A simple storage based approach was designed within the AWRA-R modelling platform to model floodplain fluxes and storages. During any flood event, flow in a river reach within a floodplain is partitioned into two components, instream and overbank flow, based on the in-stream capacity. A flood volume-area relationship, derived from MODIS-SRTM based inundation volume-area time series, is used to estimate flooded area for the overbank flow. The losses due to evaporation and groundwater recharge from the floodplain are calculated using the estimated flooded area.

The model was implemented in all floodplain river reaches across the MDB. The inundation modelling parameters were calibrated as part of the step-wise calibration of the AWRA-R model. The model has produced the daily time series of floodplain stores and fluxes. The mass-balance analysis shows that the long term mass-balance error was negligible for all floodplain reaches.
\end{abstract}

Keywords: Flood inundation modelling, River System model, Wetlands, Murray-Darling Basin, Water Resources Planning, Water Resources Accounting 


\section{INTRODUCTION}

The Australian Water Resources Assessment system (AWRA) is developed jointly by CSIRO and the Australian Bureau of Meteorology as part of the Water Information Research and Development Alliance (WIRADA). The system supports the Bureau in the production of the National Water Accounts (NWA) and the Australian Water Resources Assessment (AWRA) reports, which provides an overview of water fluxes and storages at the national scale. Both products implement the Water Balance Framework introduced by Barratt (2008). The AWRA system is built around three components covering different parts of the water cycle: AWRA-L is the landscape component, AWRA-R focuses on river systems and AWRA-G covers the groundwater. The core objective of the AWRA-R model is to support the production of the NWA and AWRA reports. The NWA reports the status of water resources for a given set of reporting regions over a defined water year. Reporting revolves around useable water in the surface water store (rivers and reservoirs), the groundwater store, an irrigation store where appropriate, and an urban store where appropriate. AWRA-R is developed to estimate terms particularly relating to the surface water store, with various NWA fluxes (Lerat et al., 2013).

Floodplains and wetlands are a critical part of natural environment and they play important hydrological and ecological roles in river basins. Water management authorities and river managers require detailed understanding of overbank flows and floodplain fluxes to plan environmental flows to optimise the environmental benefits to the riparian ecosystem. Satellite based techniques (Shaikh et al., 2001; Colloff et al., 2010) and hydrodynamic models (Dutta et al., 2007) are widely used for floodplain inundation mapping and modelling. However, it is cumbersome to integrate these approaches with any of the existing river system models, which are integral parts of water resources accounting, planning and management (Dutta et al., 2012; Welsh et al., 2013; Dutta et al., 2013).

The main aim of this research was to develop a simplified methodology for flood inundation simulation within AWRA-R river system modelling framework to enhance the flood inundation modelling capability for quantifying floodplain fluxes. Towards estimating the floodplain leakage, evaporation and storage more accurately, two conceptual storage-based approaches were designed. The first approach is a simple storagebased method suitable for data limited environments. The second approach is more comprehensive and suitable for areas with high resolution data such as LiDAR topography data. The paper describes the first approach and its implementation across the floodplains in the Murray-Darling Basin.

\section{METHODOLOGY}

AWRA-R is a conceptual hydrological model, in which a river system is schematised into a simplified river network using a node-link structure. The river network begins and ends with a node, and all nodes are interconnected by links. Runoff from gauged or ungauged tributaries or local contributing area between two nodes is fed into the connecting link as an inflow at the relevant location and all other physical processes (such as diversions, groundwater fluxes, overbank flow) occurring between the two nodes are incorporated in the model. A step-wise auto-calibration procedure is used for calibration of AWRA-R (Hughes et al., 2013). For a river reach (Figure 1), the general form of the water balance equation used in the updated auto-calibration procedure (incorporating overbank flow component) for a reach is as follows:

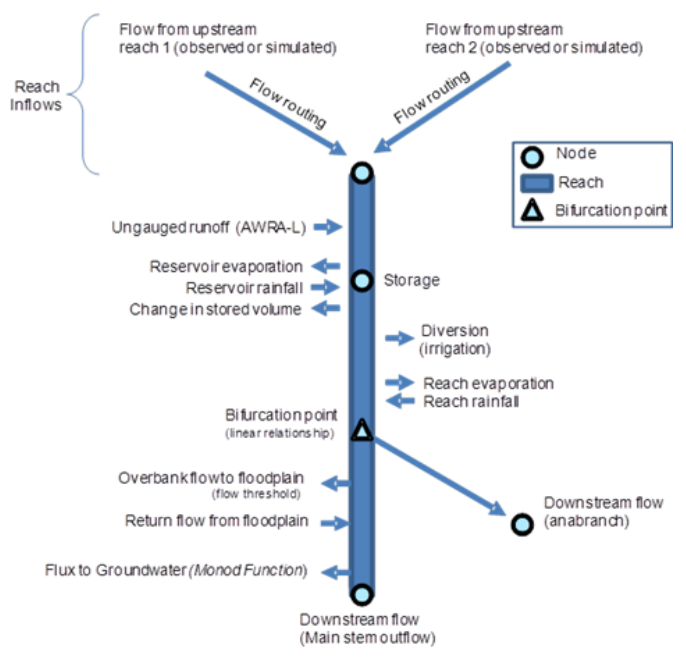

Figure1. Conceptual representation of a river reach within AWRA-R

where, $\widehat{Q_{d / s}}$ is the estimated flow at the downstream gauge, $Q_{u / s}$ is concurrent flow at the upstream gauges (including gauged tributaries) following routing, $Q_{r}$ is the runoff locally generated, $Q_{s}$ is the contribution from any storages including rainfall on storage area, evaporation from storage area and change in storage volume, $Q_{d}$ is the loss due to irrigation diversion, $Q_{p}$ and $Q_{e}$ are the fluxes to and from the river due to rainfall and evaporation, respectively, $Q_{\mathrm{a}}$ is the flow diverted to anabranches, $Q_{f}$ is overbank flow to floodplain, $Q_{f p r}$ is return flow from floodplain, $Q_{g w}$ is the flux from river to groundwater. 


\subsection{Storage-based inundation modelling approach}

This approach is developed from first principles relating to water balance and system dynamics. A river reach in a floodplain is considered to have two storages: in-stream storage and floodplain storage (Figure 2). During a flood event, flow in a floodplain river reach is partitioned into two components, in-stream and overbank flow, based on the average in-stream storage capacity. The in-stream capacity is estimated by averaging the river channel volumes (upto the bank threshold) of the $\mathrm{u} / \mathrm{s}$ and $\mathrm{d} / \mathrm{s}$ gauges using the cross-section data at the two nodes. It is assumed water from a river reach spills over to the adjacent floodplain if flow volume exceeds the in-stream storage capacity. The water balance equation for a floodplain along a river reach is shown below.

$\widehat{V_{f p(t)}}=V_{f p(t-1)}+Q_{f p}-Q_{f p r}+(P-E T-G W S) * A_{f p}$

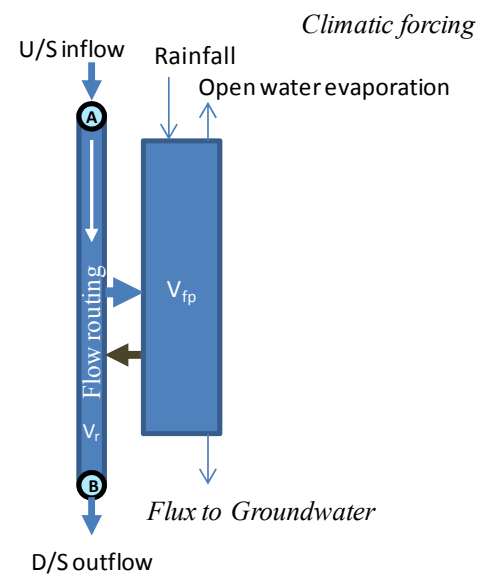

Figure 2. Conceptualisation of river and floodplain storages

where, $\widehat{V_{f p(t)}}$ is the estimated floodplain storage at current timestep, $V_{f p(t-1)}$ is the floodplain storage at previous time step, $Q_{f p}$ is overbank flow to floodplain, $Q_{f p r}$ is return flow from floodplain, $P$ is precipitation rate, ET is evaporation rate, GWS is saturated infiltration rate and $A_{f p}$ is average floodplain area.

In the auto-calibration procedure, overbank flow from a river reach to the adjacent floodplain is calculated based on the average in-stream storage capacity of the reach. It is assumed that water from the river reach will spill over the floodplain when the flow rate becomes larger than the in-stream storage capacity. The rate of overbank flow is estimated using the following equation.

$$
\widehat{\mathrm{Q}_{\mathrm{fp}}}=\left\{\begin{array}{c}
0, \mathrm{Q}_{0}<0 \\
\mathrm{Q}_{0}, 0<Q_{0}<1 \\
\mathrm{Q}_{0}{ }^{\mathrm{a}}, \mathrm{Q}_{0} \geq 1
\end{array}\right.
$$

where, $\mathrm{Q}_{0}$ is flow defined as $\mathrm{Q}_{0}=\left(\mathrm{Q}_{\mathrm{u} / \mathrm{s}}+\mathrm{Q}_{\mathrm{g}}-\mathrm{Q}_{\mathrm{l}}\right)_{\text {rout }}-\mathrm{V}_{\mathrm{sc}} / \Delta \mathrm{t}, V_{s c}$ is the in-stream capacity, and $a$ is a coefficient (ranges between 0 to 1 ), which is calibrated as part of the auto-calibration procedure.

To calculate net loss from or gain to floodplain due to evaporation, groundwater infiltration and rainfall, the flooded area was estimated from the floodplain storage volume using a linear volume-area relationship as shown below;

$$
\widehat{\mathrm{A}_{\mathrm{fp}}}=\theta \mathrm{V}_{\mathrm{fp}}
$$

where, $\widehat{A_{f p}}$ is the estimated inundation area (unit: $\mathrm{m}^{2}$ ), $V_{f p}$ is the floodplain storage (unit: $\mathrm{m}^{3}$ ) obtained from equation (2) and $\theta$ is a coefficient. This coefficient was initially derived from the time series of MODIS satellite imagery and SRTM DEM for all modelling reaches (Gouweleeuw et al., 2011). However, the derived values for many reaches were found to be very low and finally, it was decided to use the minimum slope value of 0.5 (based on LiDAR analysis in few reaches). The return flow from floodplain is estimated as follows:

$$
\widehat{Q_{f p r}}=\left\{\begin{array}{r}
\alpha V_{f p}{ }^{\beta}, V_{f p}<\alpha^{1 /(1-\beta)} \\
V_{f p}, V_{f p} \geq \alpha^{1 /(1-\beta)}
\end{array}\right.
$$

where, $\alpha<1$ and $\beta \geq 1$ are two calibrating parameters, calibrated as part of the auto-calibration procedure. If $\beta=1$, the equation system (5) reduces to $\widehat{\mathrm{Qfpr}_{\mathrm{fr}}}=\alpha \mathrm{V}_{\mathrm{fp}}$.

\section{STUDY AREA AND DATA}

The Murray-Darling Basin (MDB) is the second largest Australian river basin covering an area of approximately 1 million $\mathrm{km}^{2}$. The transboundary river basin, shared by four states and one territory, is Australia's most important agriculture region producing one third of Australia's food supply. For the purpose of modelling, the entire MDB was divided into 18 contiguous regions based on the regional boundaries used in the Murray-Darling Basin Sustainable Yields Project (CSIRO, 2008) (Figure 3a). AWRA-R includes all regions except the Eastern Mount Lofty Ranges (EMLR) region, which represents less than 1\% of the total area of the basin and does not contribute significant water to the Murray River. Not all modelling reaches of a river system are located in floodplains and for implementation of the inundation modelling, it is required to 
identify the modelling reaches that are located in the floodplains. A 1:100 year return period maximum flood inundation extent map derived from MODIS satellite imagery (Figure 3b) (Chen et al., 2012) was used to identify the flood reaches in MDB. The daily time series of inundation volume and area of historical floods developed by Gouweleeuw et al. (2011) using MODIS imagery and SRTM DEM were used to establish the volume-area relationships for different floodplain reaches. Saturated infiltration rates for the floodplains connecting different modelling reaches were derived based on the regional soil texture classification map of Australia (Henderson et al., 2001). Figure 3c shows the texture classification map of MDB showing five classes maps for the topsoil model: sands, sandy loams, loams, clay loams / light clays and clays.

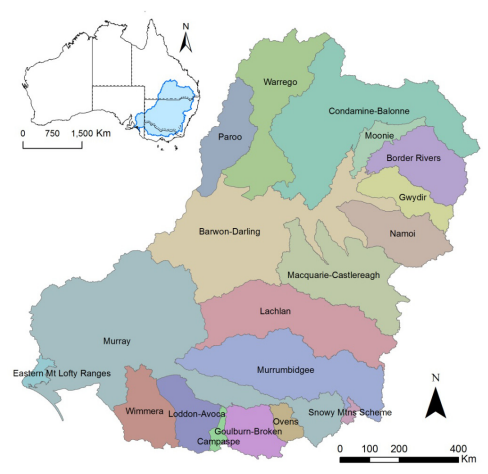

a)

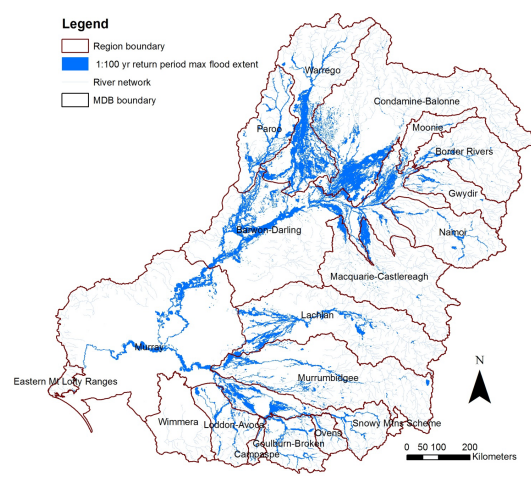

b)

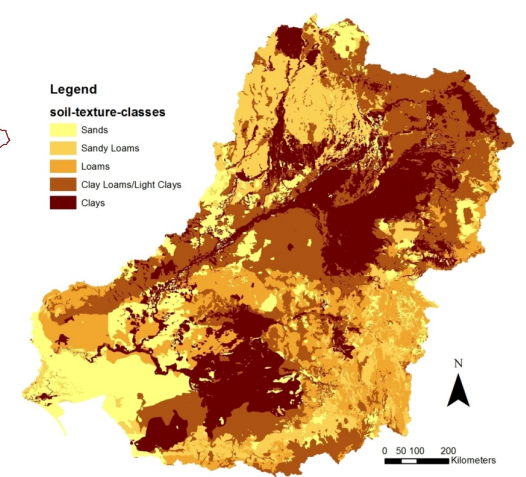

c)

Figure 3. Maps of the Murray-Darling Basin showing a) modelling regions; b) maximum extent of 1:100 yr return period inundation map; and c) soil texture classes for top layer

\section{RESULTS AND DISCUSSION}

Flood inundation modelling in AWRA-R was implemented in 216 reaches of the MDB. The modelling parameters were calibrated as part of the step-wise calibration of AWRA-R model for all components including the parameters of flow routing and groundwater monod functions for the period of 1975-1999. The model was validated using more recent data for 2000-2012. The flood module was invoked in the joint calibration for floodplain reaches and the parameters were calibrated with the observed downstream flow data. There was no other ground based observed data available for calibration of the parameters of the inundation model. Many of the floodplain reaches are located within the environmental assets of MDB and these floodplains are highly

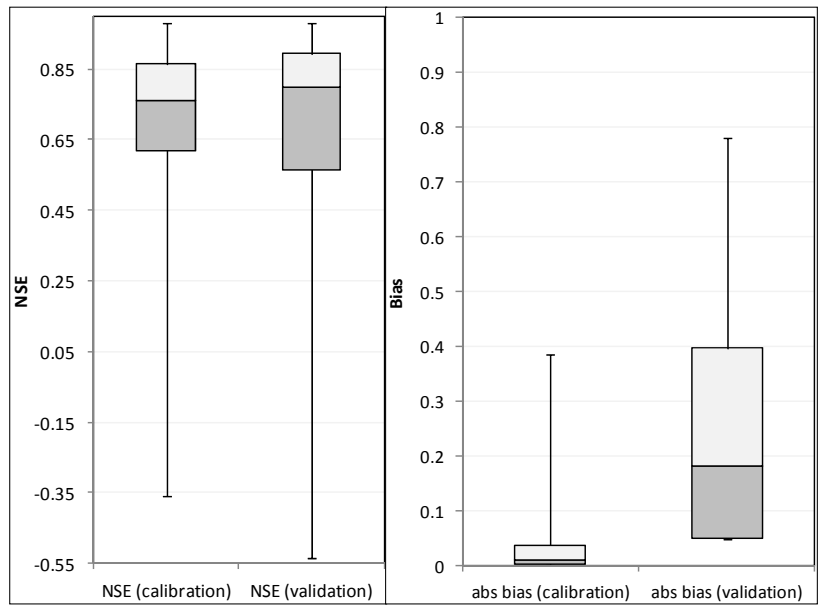

Figure 4. Statistics of NSE and Bias during the calibration and validation of the selected floodplain reaches significant for the biodiversity and aquatic ecosystem of the basin. Several studies were undertaken to model and map the inundation characteristics in these areas of MDB for improving the environmental flow in the wetland ecosystem of the basin (Colloff et al., 2010). Chen et al., 2012 divided the basin into 95 ecohydrological zones and listed the flow gauging stations located within the environmentally sensitive areas of the basin. Table 1 shows lists of the modelled AWRA-R floodplain gauges that are included in the list. Table 2 presents the statistics of calibration and validation of the AWRA-R model for these selected floodplain reaches. Figure 4 presents the summary of the daily NSE and bias for these reaches for the periods of calibration and validation. The results show that the performance of the AWRA-R flood inundation model are highly satisfactory in most of the floodplain reaches with median NSE of 0.76 and mean bias of $14.3 \%$ in calibration. The calibrated parameters of AWRA-R including the calibrated floodplain parameters performed well in the validation period with median NSE of 0.79 and median bias of $23.2 \%$, which are close to the results obtained in the calibration period. Out of the 27 selected gauges, the model did not perform well in one reach (end gauge 418052) in the calibration with NSE below zero and for three gauges reaches (412011, $418055,421040)$ the calibrated NSE were below 0.5 . For these gauges, the calibrated model did not perform well in the validation period as well. 
Dutta et al., A simple storage based floodplain inundation modelling approach in AWRA-R

The floodplain reaches consist of $37 \%$ of the total modelling reaches of AWRA-R in MDB. To understand relative performance of AWRA-R model in floodplain reaches compared to the overall performance, the statistical summary of the performance of the model in floodplain reaches are compared with the overall model performance for different regions. Figure 5 compares the average NSE statistics of the model for the floodplain reaches and the entire region for different regions of MDB for the entire period of simulation. The results of Paroo, Moonie, Warrego and Wimmera are not included as the number of floodplain reaches in these regions is less than 3. The results show that for most of the regions (Condamine-Balonne, Namoi, Macquarie-castlereagh, Lachlan, Murrumbidgee, Goulburn-Broken and Loddon-Avoca), the agreement between of the observed and simulated flow in floodplain reaches are similar to other reaches. The agreements are better in floodplain reaches for Barwon-Darling and Murray regions. For the Border rivers and Gwydir regions, the agreement in floodplain reaches were lower than the regional average. The variability was lower in most of the regions except for the Campaspe region. The lengths of the recorded data at many of the gauging stations in Campaspe are relatively short with many missing points. Dutta et al., 2012 reported similar uncertainty in river system modelling in Campaspe.

Table 1. Floodplain reaches located within environmental asset zones of MDB and their characteristics

\begin{tabular}{|c|c|c|c|c|}
\hline Region & End gauge of floodplain reach & $\begin{array}{l}\text { Reach } \\
\text { length } \\
(\mathrm{km})\end{array}$ & $\begin{array}{l}\text { Max recorded } \\
\text { discharge } \\
\text { (ML/day) }\end{array}$ & $\begin{array}{c}\text { Max Flooded } \\
\text { area }\left(\mathrm{km}^{2}\right) \\
\text { (modelled) }\end{array}$ \\
\hline Border Rivers & 416012 (Macintyre@Holdfast; Yelarbon Crossing) & 50 & 117,189 & 234 \\
\hline Condamine Balonne & 422015 (Culgoa@Brenda) & 57 & 77,821 & 110 \\
\hline Condamine Balonne & 422016 (Narran at Wilby Wilby) & 132 & 10,914 & 89 \\
\hline Condamine Balonne & 422213 (Balonne@Weribone) & 178 & 339,527 & 246 \\
\hline Condamine Balonne & 422325 (Condamine@Cotswold) & 152 & 353,873 & 260 \\
\hline Condamine Balonne & 422401 (Maranoa@Mitchell) & 98 & 131,195 & 165 \\
\hline Condamine Balonne & 422404 (Maranoa@Cashmere) & 177 & 126,011 & 156 \\
\hline Gwydir & 418001 (Gwydir@Pallamallawa) & 49 & 155,451 & 184 \\
\hline Gwydir & 418052 (Carole Creek at Near Garah) & 61 & 8,955 & 55 \\
\hline Gwydir & 418055 (Mehi@near Collarenebri) & 176 & 9,423 & 58 \\
\hline Lachlan & 412011 (Lachlan at Lake Cargellico Weir) & 44 & 12,487 & 19 \\
\hline Macquarie Castlereagh & 421025 (Macquarie@Bruinbun) & 176 & 168,628 & 88 \\
\hline Macquarie Castlereagh & 421040 (Macquarie@D/S Burrendong Dam) & 88 & 176,614 & 148 \\
\hline Moonie & 417001 (Moonie@Gundablouie) & 37 & 43,607 & 116 \\
\hline Murray & 401202 (Mitta Mitta River at Mitta Mitta) & 146 & 49,211 & 37 \\
\hline Murray & 402205 (Kiewa@Bandiana) & 154 & 39,594 & 93 \\
\hline Murray & 409002 (Murray@Corowa) & 107 & 190,601 & 148 \\
\hline Murrumbidgee & 410001 (Murrumbidgee@Wagga Wagga) & 131 & 443,820 & 289 \\
\hline Murrumbidgee & 410004 (Murrumbidgee@Gundagai) & 27 & 456,704 & 24 \\
\hline Murrumbidgee & 410130 (Murrumbidgee@D/S Balranald Weir) & 13 & 26,951 & 72 \\
\hline Namoi & 419006 (Peel@Carrol Gap) & 68 & 136,679 & 133 \\
\hline Namoi & 419007 (Namoi@D/S Keepit Dam) & 47 & 104,397 & 134 \\
\hline Namoi & 419020 (Manilla@Brabri (Merriwee) & 23 & 40,115 & 77 \\
\hline Namoi & 419026 (Namoi@Goangra) & 66 & 109,948 & 129 \\
\hline Namoi & 419068 (Namoi@D/S Weeta Weir) & 16 & 64,038 & 178 \\
\hline Ovens & 403200 (Ovens@Wangaratta) & 49 & 53,303 & 125 \\
\hline Paroo & 424002 (Paroo@Willara Crossing) & 99 & 225,117 & 147 \\
\hline
\end{tabular}

\subsection{Floodplain Fluxes and mass balance}

One of the key objectives of the inundation model was to produce floodplain fluxes. Figure 6 shows the daily time series of four floodplain fluxes: 1) overbank flow to floodplain, 2) return flow from floodplain, 3) net loss from floodplain due to evaporation and groundwater recharge, and 4) floodplain storage volume, for two floodplain reaches in Paroo and Moonie for the entire period of simulation. As can be seen from the figure, for all flood events, flux terms in floodplain are produced by the model. The variation of flooded area over time during the flood events are also shown in the figure. The mass-balance analysis shows that the long term mass balance error was negligible for all floodplain reaches.

Table 2. Statistical summary of calibration and validation of the selected floodplain reaches

\begin{tabular}{|c|c|c|c|c|c|c|c|c|c|c|}
\hline \multirow{2}{*}{$\begin{array}{c}\text { End } \\
\text { gauge ID }\end{array}$} & \multicolumn{4}{|c|}{ calibration } & \multicolumn{4}{c|}{ Validation } \\
\cline { 2 - 11 } & start & end & bias & NSE & NSELOG & start & end & bias & NSE & NSELOG \\
\hline $\mathbf{4 0 2 2 0 5}$ & $24 / 07 / 1974$ & $8 / 05 / 1997$ & -0.10 & 0.91 & 0.94 & $9 / 04 / 1992$ & $3 / 11 / 2011$ & -0.13 & 0.90 & 0.91 \\
\hline
\end{tabular}


Dutta et al., A simple storage based floodplain inundation modelling approach in AWRA-R

\begin{tabular}{|c|c|c|c|c|c|c|c|c|c|c|}
\hline 403200 & $2 / 11 / 1985$ & $20 / 10 / 1993$ & 0.22 & 0.59 & 0.73 & $20 / 10 / 1988$ & $6 / 10 / 1996$ & 0.23 & 0.56 & 0.73 \\
\hline 409002 & $1 / 01 / 1970$ & $14 / 05 / 1993$ & -0.01 & 0.98 & 1.00 & $14 / 05 / 1988$ & $15 / 06 / 2011$ & -0.01 & 0.98 & 1.00 \\
\hline 410001 & $1 / 01 / 1970$ & $4 / 11 / 1992$ & 0.00 & 0.93 & 0.99 & $5 / 11 / 1987$ & $7 / 09 / 2010$ & 0.04 & 0.93 & 0.99 \\
\hline 410004 & $1 / 01 / 1970$ & $27 / 10 / 1992$ & 0.00 & 0.89 & 0.97 & $28 / 10 / 1987$ & $23 / 08 / 2010$ & 0.00 & 0.91 & 0.97 \\
\hline 410130 & $29 / 06 / 1979$ & 9/11/1997 & -0.13 & 0.76 & 0.80 & 9/11/1992 & $17 / 05 / 2011$ & 0.06 & 0.74 & 0.89 \\
\hline 412011 & $25 / 09 / 1970$ & $12 / 10 / 1993$ & 0.00 & 0.43 & 0.58 & $12 / 10 / 1988$ & $7 / 12 / 2011$ & -0.34 & -0.41 & 0.13 \\
\hline 416012 & $26 / 10 / 1972$ & $17 / 01 / 1995$ & -0.02 & 0.78 & 0.96 & $17 / 01 / 1990$ & $25 / 02 / 2011$ & 0.09 & 0.77 & 0.97 \\
\hline 417001 & $18 / 12 / 1970$ & $6 / 09 / 1993$ & -0.01 & 0.93 & 0.98 & $6 / 09 / 1988$ & $19 / 05 / 2011$ & -0.03 & 0.97 & 0.99 \\
\hline 418001 & $2 / 09 / 1972$ & $26 / 06 / 1994$ & 0.00 & 0.87 & 0.98 & $26 / 06 / 1989$ & $9 / 03 / 2011$ & 0.03 & 0.83 & 0.98 \\
\hline 418052 & $9 / 10 / 1980$ & $22 / 07 / 1998$ & -0.01 & -0.36 & -1.68 & $22 / 07 / 1993$ & $28 / 06 / 2011$ & 0.22 & -0.31 & -1.70 \\
\hline 418055 & $19 / 06 / 1980$ & $21 / 12 / 1998$ & -0.01 & 0.23 & 0.36 & $30 / 08 / 1993$ & $18 / 05 / 2011$ & -0.17 & 0.36 & 0.50 \\
\hline 419006 & $6 / 03 / 1973$ & $22 / 10 / 1994$ & 0.00 & 0.67 & 0.88 & $22 / 10 / 1989$ & $31 / 05 / 2011$ & 0.26 & 0.80 & 0.96 \\
\hline 419007 & $27 / 06 / 1973$ & $25 / 12 / 1994$ & 0.00 & 0.53 & 0.46 & 25/12/1989 & $31 / 05 / 2011$ & 0.13 & 0.21 & 0.14 \\
\hline 419020 & $2 / 02 / 1977$ & $5 / 12 / 1996$ & -0.01 & 0.82 & 0.93 & $6 / 12 / 1991$ & $2 / 06 / 2011$ & 0.21 & 0.92 & 0.98 \\
\hline 419026 & $10 / 02 / 1971$ & $12 / 03 / 1994$ & -0.01 & 0.85 & 0.95 & $12 / 03 / 1989$ & $3 / 05 / 2011$ & 0.10 & 0.89 & 0.97 \\
\hline 419068 & $3 / 11 / 1978$ & $19 / 07 / 1997$ & 0.01 & 0.62 & 0.85 & $3 / 11 / 1978$ & $19 / 07 / 1997$ & -0.11 & 0.57 & 0.87 \\
\hline 421025 & $1 / 01 / 1970$ & $6 / 04 / 1993$ & 0.00 & 0.61 & 0.81 & $29 / 02 / 1988$ & $17 / 05 / 2011$ & 0.38 & 0.66 & 0.86 \\
\hline 421040 & $18 / 12 / 1970$ & $13 / 05 / 1994$ & -0.06 & 0.32 & 0.62 & $28 / 04 / 1989$ & $26 / 05 / 2011$ & 0.14 & 0.26 & 0.59 \\
\hline 422015 & $1 / 01 / 1970$ & $28 / 01 / 1993$ & -0.01 & 0.89 & 0.96 & $5 / 12 / 1987$ & $28 / 02 / 2011$ & 0.16 & 0.89 & 0.94 \\
\hline 422016 & $1 / 01 / 1970$ & $4 / 11 / 1994$ & 0.00 & 0.69 & 0.85 & $7 / 05 / 1989$ & $12 / 08 / 2011$ & 0.34 & -0.53 & -0.30 \\
\hline 422213 & $1 / 01 / 1970$ & $27 / 12 / 1993$ & 0.00 & 0.74 & 0.90 & $20 / 07 / 1988$ & $1 / 07 / 2011$ & 0.04 & 0.80 & 0.96 \\
\hline 422325 & $1 / 01 / 1970$ & $18 / 05 / 1994$ & -0.04 & 0.86 & 0.95 & $16 / 01 / 1989$ & $15 / 02 / 2011$ & 0.01 & 0.89 & 0.96 \\
\hline 422401 & $20 / 11 / 1972$ & $14 / 09 / 1996$ & -0.35 & 0.69 & 0.87 & $23 / 03 / 1989$ & $29 / 06 / 2011$ & -0.19 & 0.61 & 0.76 \\
\hline 422404 & $27 / 02 / 1970$ & $29 / 03 / 1992$ & -0.07 & 0.82 & 0.93 & $6 / 03 / 1986$ & $29 / 06 / 2011$ & -0.11 & 0.79 & 0.93 \\
\hline 424002 & $30 / 11 / 1975$ & $9 / 01 / 1996$ & 0.00 & 0.67 & 0.85 & 9/01/1991 & $18 / 02 / 2011$ & 0.22 & 0.87 & 0.92 \\
\hline
\end{tabular}

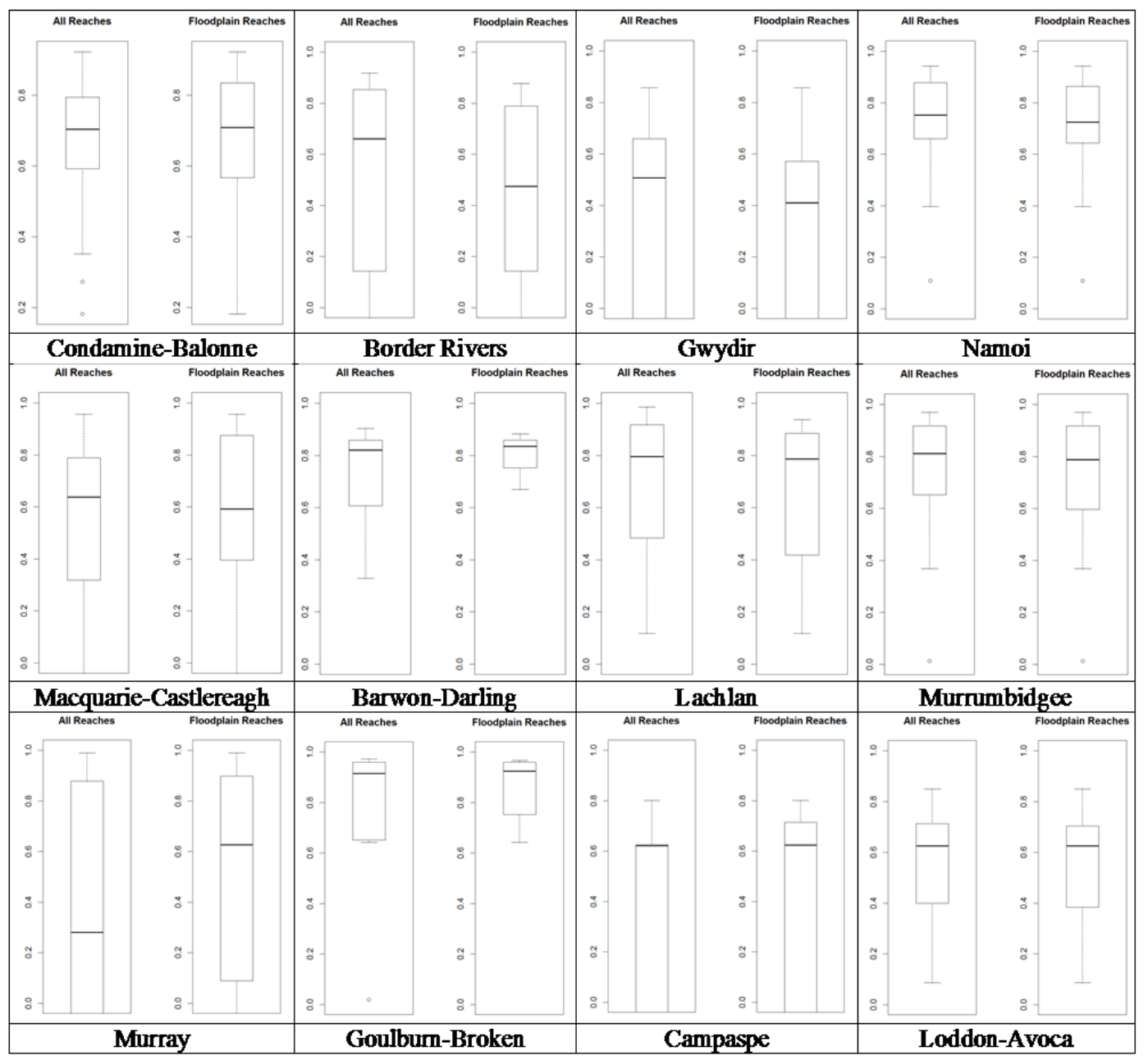

Figure 5. Statistics of average NSE for the region (left) and for the reaches located within the floodplains for the simulated and observed flows for different regions of MDB 


\section{CONCLUSIONS}

This paper describes the development and implementation of the floodplain inundation component of AWRA-R modelling system. A simplified storage-based floodplain inundation modelling approach was successfully developed for AWRA-R model and tested in the MurrayDarling Basin. The approach is a single storage approach, where river flow is partitioned into in-stream and overbank flow based on the in-stream flow capacity in floodplain reaches. The approach was implemented in all floodplain reaches of MDB.

AWRA-R model with the floodplain inundation module performed reasonably well in most of the floodplain reaches in both calibration and validation periods. The NSE values of the simulated results in floodplain reaches in most of the regions (Condamine-Balonne, Namoi, Macquarie-Castlereagh, Lachlan, Murrumbidgee, Goulburn-Broken and Loddon-Avoca) were similar to the overall regions. The agreements are better in floodplain reaches for Barwon-Darling and Murray regions. For the Border Rivers and Gwydir regions, the agreements in floodplain reaches were less than the regional average. The variability was lower in most of the regions except for the Campaspe region. Average bias in the floodplain reaches in most of the regions is similar. The model has produced the daily time series of floodplain stores and fluxes. The mass-balance analysis shows that the long term mass balance error was negligible for all floodplain reaches. The approach significantly improves the flood inundation modelling capability of the AWRA-R river system model and improves the water balance analysis by quantifying the flux terms for water accounting.

\section{REFERENCES}

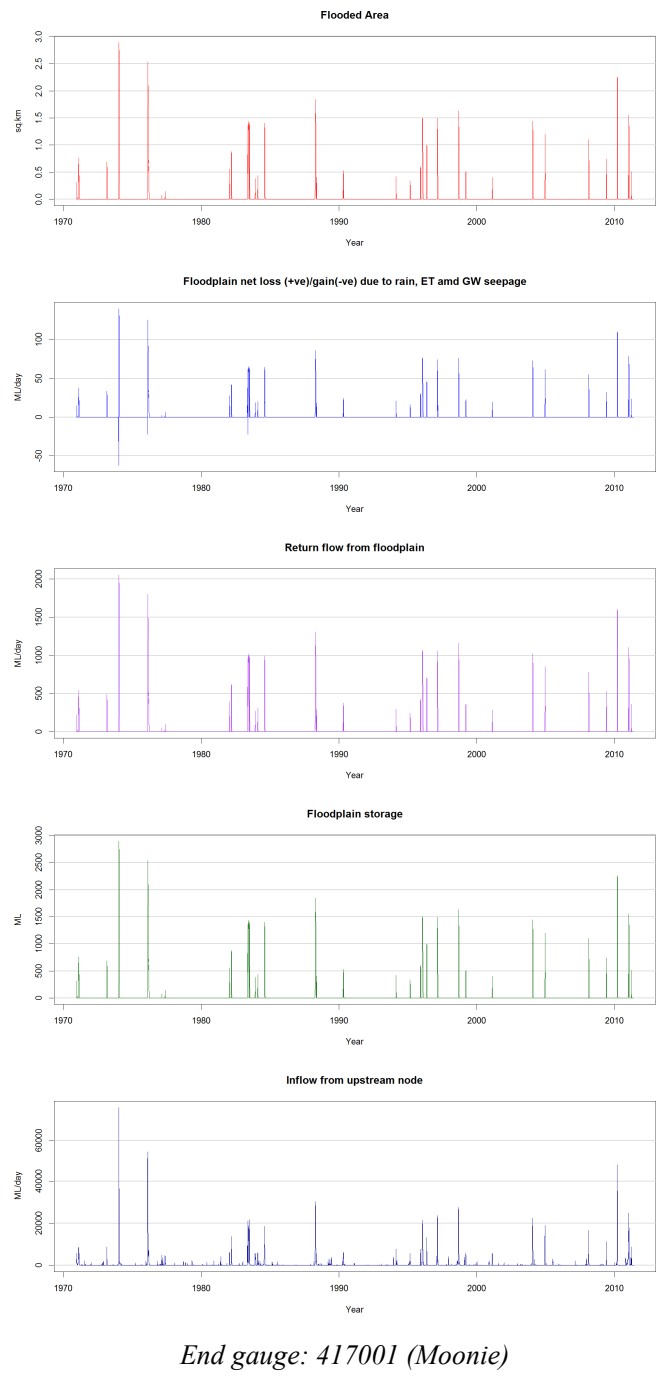

Figure 6. Daily time series of floodplain fluxes along a floodplain reach in Moonie

Barratt DG (2008). A Proposed National Water Balance Framework. Water Division, Bureau of Meteorology.

Chen Y, Cuddy SM, Merrin LE, Huang C, Pollock D, Sims N, Wang B, Bai Q (2012). Murray-Darling Basin Floodplain Inundation Model Version 2.0 (MDB-FIM2), Technical report. CSIRO Water for a Healthy Country Flagship.

Colloff MJ, Overton IC, Cuddy SM, Doody TM, Henderson B, Capon SJ (2010). Improving environmental water planning and policy outcomes: ecological responses to flow regimes in the Murray-Darling Basin, Waterlines report, NWC, Canberra.

CSIRO (2008). Water availability in the Murray-Darling Basin. A report to the Australian Government from the CSIRO Murray-Darling Basin Sustainable Yields Project. CSIRO, Australia.

Dutta D, Alam J, Umeda K, Hayashi M, Hironaka S (2007). A two dimensional hydrodynamic model for flood inundation simulation: a case study in the Lower Mekong River basin, Hydrological Processes, 21:1223-1237.

Dutta D, Hughes J, Vaze J, Kim S, Yang A, Podger G (2012). A Daily River System Model for the Murray-Darling Basin: Development, Testing and Implementation, Proceedings of the 34th Hydrology \& Water Resources Symposium, Sydney, 1057-1066.

Dutta D, Wilson K, Welsh W, Nicholls D, Kim S, Cetin L (2013). A New Modelling System for River Operations with a Case Study from the Goulburn River, Australia, Journal of Environmental Management, 121:13-28.

Gouweleeuw B, Ticehurst C, Thew P (2011). Surface water volume estimation in support of water accounting. CSIRO.

Henderson, B., B. Elisabeth, C. Moran, D. Simon and P. Carlile (2001). ASRIS: Continental-scale soil property predictions from point data, Technical report 28/01, CSIRO Land and Water, Canberra, Australia, 109p.

Hughes J, Dutta D, Kim S, Vaze J, Podger G (2013). An automated multi-step calibration procedure for a river system model, Environmental Modelling \& Software (in press).

Lerat J, Dutta D, Kim S, Hughes J, Vaze J, Dawes W (2013). Refinement and extension of the AWRA-R model, CSIRO: Water for a Healthy Country National Research Flagship, Australia, 62p.

Shaikh M, Green D, Cross H (2001). A remote sensing approach to determine environmental flows for wetlands of the Lower Darling River, New South Wales, Australia. Int. J. Remote Sensing, 22(9):1737-1751.

Welsh W, Vaze J, Dutta D, Rassam D, Rahman J, Jolly I, Wallbrink P, Podger G, Bethune M, Hardy M, Teng J, Lerat J (2013). An integrated modelling framework for regulated river systems, Environmental Modelling \& Software, 39:81-102. 